\title{
Protection of Healthcare Workers' Rights by Trade Unions and Biological Hazards in Ukraine
}

\author{
Yurii P. Burylo, Sergii Y. Vavzhenchuk, Mariia V. Protsyshen
}

\begin{abstract}
The article deals with the issues of protecting the labor rights of healthcare workers by trade unions. In particular, special attention is paid to the doctrinal and legal foundations of protecting the labor rights of medical professionals by trade unions as well as the legal regulation of trade unions' activities, their rights and duties aimed at the execution of labor rights protection function in healthcare sector. It is also emphasized that there is a great need to improve the protection of healthcare workers' rights in the light of numerous biological hazards in the healthcare sector. By the means of system analysis, historical and comparative methods a number of gaps and inconsistencies in the current Ukrainian legislation concerning the powers of trade unions and the rights healthcare workers have been revealed. Ways to improve this legislation by addressing those gaps and inconsistencies have been suggested.
\end{abstract}

Keywords : labor rights of healthcare workers, protection of healthcare workers' labor rights, trade unions in healthcare sector, powers of trade unions, biological hazards.

\section{INTRODUCTION}

The legal framework of protecting the labor rights of healthcare workers by trade unions has become one of the crucial points in legal research as well as an important direction in the development of both medical and labor law in recent years, even though legal scholars took interest in this subject at different points in history. That's why Ukrainian legislation establishing this framework has been in a state of permanent development over the last decade. Under the influence medical and labor law doctrine the essence and the form of this legislation have been undergoing constant transformation and improvement like a live organism. However, it should be pointed out that the dynamic transformation of the Ukrainian legislation has brought about positive changes in medical and labor law along with a number of latent flaws exacerbating existing problems in the legal framework of protecting the labor rights of healthcare professionals. In particular, the current legislation does not provide for proper protection of healthcare workers' rights by trade unions when it comes to occupational biological hazards.

Therefore, there is a need for a critical analysis of such problems as well as ways to tackle them.

Revised Manuscript Received on November 15, 2019

* Correspondence Author

Yurii P. Burylo, Kyiv National Economic University of Vadim Hetman, Kyiv, Ukraine, , idorcid.org /0000-0001-8743-7739

Sergii Y. Vavzhenchuk, Taras Shevchenko National University of Kyiv,Kyiv, Ukraine, idorcid.org/0000-0002-6968-6720

Mariia V. Protsyshen, Kyiv National Economic University of Vadim Hetman,Kyiv, Ukraine, idorcid.org/0000-0001-8969-3808

\section{MATERIALS AND METHODS}

\subsection{General background of trade unions'} transformation, medical reform and biological hazards

The establishment of trade unions in the healthcare sector of Ukraine differs from the creation of their counterparts in other countries, considering the fact that the contemporary trade union movement in Ukraine began only when the country declared independence in 1991. Under such difficult circumstances health workers' trade unions began their transformation by getting rid of communist heritage and management structure as well as turning their attention to international standards of labor rights protection.

Nowadays, a number of tasks for the health workers' trade unions come as the priorities. The first of such priorities is to make sure that healthcare workers' rights are respected by their employers. Since hospitals are usually large employers, the function of trade unions to verify the observance of health workers' rights is very important. The second priority of trade unions is to prevent the restriction of labor rights and guarantees when relevant laws and regulations are drafted and passed. In this regard the participation of health workers' trade unions is highly important during medical reform, when numerous new regulations are still being prepared. During this reform it is particularly important to create effective safeguards for medical professionals against occupational hazards, including biological hazards. The third priority is to ensure social partnership in the healthcare sector, making it possible to reconcile legitimate interests of healthcare workers with relevant interests of their employers. The fourth priority is to ensure that there are proper legal tools and other arrangements in place for the protection of healthcare workers against occupational biological hazards.

It's worth pointing out that the implementation of these priorities is hampered by a number of factors. The most significant of such factors is the opposition of some employers to the establishment of healthcare workers' trade unions. Another drawback is the lack of competition between healthcare workers' trade unions due to the fact that as a rule there is only one trade union in a hospital. If there were more trade unions it would enhance the protection of labor rights as a result of competition. Besides, the lack of proper legal regulation and new codification of labor law contribute to legal uncertainty regarding the protection of healthcare workers' labor rights.

Protection of healthcare workers' rights is the responsibility of the Healthcare Workers' Trade Union of Ukraine, which is one of the biggest national industrial trade unions. 
Members of this trade union are united in primary trade union organizations. As of January 2011 the Healthcare Workers' Trade Union of Ukraine consists of 27 divisions - 1 national, 24 regional and 2 city branches (in Kyiv and Sevastopol), which include 8049 primary trade union organizations with total membership of 1.128 .525 people. Over $80 \%$ of these people are women, $34 \%$ - are young people, aged under 35 , and $0,51 \%$ are those, who retired on pension without losing their membership in the trade union [1].

Protection of healthcare workers' rights has to be examined in the overall context of medical reform, which is supposed to drastically change the way healthcare sector operates in Ukraine. In particular, the current medical reform must improve the legal framework for the protection of healthcare workers' labor rights, especially their legal guarantees against occupational biological hazards, since it is argued by many researchers that workers in healthcare settings and social workers have the fourth-highest rate of work-related diseases and exposure to biological occupational hazards seems to be particularly prevalent in the healthcare sector [2]. This is confirmed by relevant statistical data [3].

Therefore, trade unions of health workers have to play a crucial role in this reform. The key role of trade unions in the medical reform can be explained by the fact that trade unions represent the interests of healthcare workers on the principles of legitimacy and transparency, laid down in article 2 of the Law of Ukraine "On trade unions, their rights and guarantees of their activity" [4].

Thus, the importance of this topic for research is caused by the flaws of the current Ukrainian legislation on the protection of healthcare workers' labor rights, including guarantees and safeguards against occupational biological hazards as well as the need to upgrade this legislation in light of the ongoing medical reform.

This article reflects the transformation of trade unions as institutions dedicated to the protection of healthcare workers' labor rights, paying particular attention to the relevant experience of the USA and Great Britain as well as the main types of trade unions and their role in modern healthcare. In this connection the works of such authors as S. Befort, $K$. Stone, S. Deakin, G. Morris, N. Lyutov, D. Chernyakova come in handy as they provide a comprehensive analysis of these countries' experience $[5$, p.352; 6, p.730; 7, p.29-30; 8 , p.121].

Against the backdrop of foreign countries' experience the current Ukrainian legislation on the protection of healthcare workers' labor rights is analyzed and its flaws are exposed, paying particular attention to the works of such scholars as V. Prokopenko, V. Nikiforov, I. Lagutina, who thoroughly examine the legal issues of protecting labor rights in Ukraine [9, p.118; 10, p.105; 11, p.175].

In particular, special attention is paid to the flaws in the Law of Ukraine "On trade unions, their rights and guarantees of their activity" and the Law of Ukraine "On the principles of healthcare legislation in Ukraine" and convergence of their provisions regarding the labor rights of healthcare workers, including legal guarantees for medical professionals against biological occupational hazards. The article also deals with the function of trade unions to protect labor rights in the healthcare sector as well as their function to represent the interests of their members. With regard to this, an attempt is made to establish if these functions can apply to healthcare workers, who are not members of trade unions.

\subsection{Transformation of trade unions as institutions dedicated to the protection of healthcare workers' labor} rights.

Collective protection of labor rights is closely linked with the very nature of a labor relationship between two opposing parties - an employee on the one hand and an employer on the other hand. As this relationship is fraught with potential conflicts of interests, the primary way to settle them is collective action of one of the parties or joint actions of both parties of such a relationship.

Among all existing institutions involved in the protection of labor rights trade unions traditionally bear the ultimate burden of collective action in case of labor disputes. Trade unions came into being as institutions responsible for taking collective action as a result of a merger between such legal methods as safeguarding and defense of labor rights for the purpose of providing more or less comprehensive protection of these rights.

It is worth pointing out that historically the right to establish trade unions as one the basic rights received international recognition in multilateral treaties many years ago, considering the fact that this particular right enabled workers to protect their other labor rights. That's why under the International Covenant on Civil and Political Rights the right to form and join trade unions is regarded as one of the most important civil rights. The fact that the International Covenant on Civil and Political Rights and other multilateral treaties single out a bunch of trade union rights testifies that these rights belong to fundamental human rights. It is clear that incorporation of labor rights into such treaties has added a lot of social and legal weight to trade union rights enhancing the level of their protection. In this respect, it should be noted that the International Covenant on Civil and Political Rights is implemented in national legislation in many countries and therefore it is regarded as a source of national law.

It should also be emphasized that article 22 (2) of the International Covenant on Civil and Political Rights as well as article 8 (1) of the International Covenant on Economic, Social and Cultural Rights lay down a presumption that the right to freedom of association, including the right to form and join trade unions, is unlimited, except for only a few restrictions $[12,13]$. Such restrictions may be placed on the exercise of this right only when they are prescribed by law and are necessary in a democratic society in the interests of national security or public safety, public order, the protection of public health or morals or the protection of the rights and freedoms of others. In other words, the exercise of this right may only be restricted according to these clear and strict criteria. Besides, the right to form and join trade unions may only be restricted at the level of the law, which requires the adoption of an act of Parliament.

Historical methodology also allows to make a conclusion that the evolution of the legal framework for the protection of labor rights by trade unions has not been smooth and flawless even in established democracies. The history of labor law is familiar with incidents when employers refused to recognize trade unions in Great Britain and employment contracts were made depriving workers of their right to join trade unions and

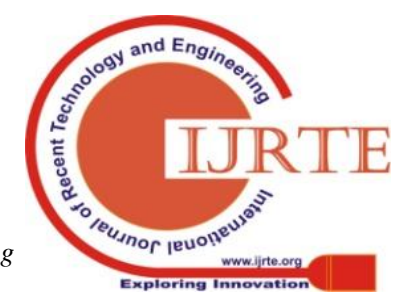


take part in their activities (strikes etc.) in the USA [7, p.36; 8, p.121]. Nonetheless, constant struggle for democratic values and the need for proper protection of labor rights have had a great impact on the development of relevant legislation in many countries. For instance, the Employment Relations Act established the procedure of compulsory recognition of trade unions in the UK, thereby introducing compulsory recognition of trade unions' collective bargaining powers and other powers to protect the interests of their members. As for the USA, the judicial system as well as lawmakers swiftly responded to such violations of labor rights and courts found relevant employment contracts to be in breach of the law. On top of that, the Law on civil rights, providing additional legal remedies for the protection of labor rights, was adopted in 1964 [8, p. 212; 14, p.91; 5, p.352].

Ukraine has also made efforts to develop its legal framework for the protection of healthcare workers' labor rights over the last two decades. Before going into details of this framework, it is necessary to pay attention to the existing legal definition of trade unions. According to article 1 of the Law of Ukraine "On trade unions, their rights and guarantees of their activity" trade unions are regarded as non-profit and non-governmental organizations with voluntary membership of people having common interests, based on their professional (labor) activity, which are established for the purpose of representation and protection of labor, social and economic rights and interests of their members (The Law of Ukraine "On trade unions, their rights and guarantees of their activity" 1999). Applying system analysis methodology to this definition set in the general context of trade unions legislation makes it possible to draw a conclusion that the law emphasizes the representation and protection of workers' rights and interests by trade unions rather than the regulation of relations between healthcare workers or healthcare workers and their employers by such organizations. It is also possible to infer that collective bargaining is one of the main functions of trade unions that is aimed at the preventative protection of healthcare workers' rights, since trade unions have relevant bargaining rights pursuant to article 20 of the Law of Ukraine "On trade unions, their rights and guarantees of their activity".

Examining the protection of labor rights and interests of healthcare workers by trade unions in a systemic manner it is necessary to point out that the scope of such protection depends to a large extent on the type of trade union to which healthcare workers belong. Using comparative research methods some western scholars have reached a conclusion that trade unions should be divided into two types - open and closed trade unions [7, p.29-30; 6, p.730]. Closed type trade unions represent and protect the labor rights of workers within one profession or a bunch of professions. For example, surgeons are entitled to form and join a surgeons' trade union. In particular, there are such closed trade unions as the Healthcare Workers' Trade Union of Ukraine, Kyiv City Trade Union of Healthcare Workers in Ukraine. Representing its members in a recent labor dispute with the Government of Ukraine the Healthcare Workers' Trade Union of Ukraine demanded to develop and adopt a national program ensuring social and economic security of healthcare workers during medical reform, including guarantees of employment, training and retraining of medical staff.

As for the trade unions belonging to the open type, they are dedicated to the representation and protection of relevant rights and interests regardless of their members' occupation.
Thus, such trade unions ensure the representation and protection of healthcare workers' rights and interests without taking into consideration the specific nature of the medical occupation.

When it comes to the exposure of healthcare workers to occupational biological hazards and the infringement of their rights related to such an exposure closed type trade unions are the best type of trade unions for representing and protecting the rights of medical personnel.

\section{RESULTS AND DISCUSSION}

\subsection{The doctrinal and legislative basis for ensuring the protection of healthcare workers' rights by trade unions.}

Considering the doctrinal and legislative foundations of ensuring the protection of healthcare workers' rights by trade unions, it makes sense to examine the links between the powers of trade unions and specific features of protecting the rights of healthcare workers.

The Ukrainian system of protecting healthcare workers' rights is based on a multi-layer legal framework. This framework includes the Constitution of Ukraine, Labor Code, the Law of Ukraine "On non-governmental organizations", the Law of Ukraine "On trade unions, their rights and guarantees of their activity", the Law of Ukraine "On employment", the Law of Ukraine "On the protection of labor", the Law of Ukraine "On wages", the Law of Ukraine "On collective contracts and agreements", the Law of Ukraine "On the procedure of collective labor disputes (conflicts) settlement", the Law of Ukraine "On the principles of healthcare legislation in Ukraine". These laws lay down the powers and duties of trade unions related to their representation and protection activities. On the whole, all the basic powers and duties of trade unions are set out in the Law of Ukraine "On trade unions, their rights and guarantees of their activity", whereas specific issues of trade unions' participation in various dimensions of employment relations are dealt with in other laws.

The Law of Ukraine "On trade unions, their rights and guarantees of their activity" lays down a variety of powers and duties of trade unions, giving legal scholars a lot of food for thought. In particular, H.I. Chanisheva and N.B. Bolotina suggest that all trade unions' powers and duties should be divided into the following categories: powers to establish collective working conditions at the level of enterprises as well as regional and industry levels; powers regarding the enforcement of labor legislation; powers to verify compliance with labor legislation [15, p.429]. Another scholar V.I. Prokopenko singles out the following powers of trade unions: powers shared with the employer; powers of approval, when the employer is entitled to make decisions subject to prior approval by trade unions; powers to take active part in the preparation of decisions made by the employer [9, p.118]. Furthermore, V.Yu. Nikiforov argues in his thesis that trade unions' powers can be arranged in a number of groups, depending on their scope and subject matter, such as powers dealing with: a) ensuring employment; b) employment contracts; c) working hours and leisure time; d) labor rationing and remuneration e) guarantees and indemnity; f) labor discipline; g) occupational 
health and safety; h) control over compliance with labor legislation; i) collective bargaining and concluding collective contracts and agreements; j) individual and collective labor dispute resolution; k) social security and insurance of workers; 1) management at enterprises, public institutions and organizations; m) information on labor, social and economic development; n) education, research, and cultural activities; o) housing and basic amenities; p) officials' accountability; r) business and financial activities of trade unions [10, p.105]. Considering the above, it becomes clear that there is no unified approach to the classification of trade unions' powers in the doctrine of labor law, which makes it more difficult to understand certain features of the legal framework designed for the protection of healthcare workers' labor rights and interests, including those related to the protection against occupational biological hazards.

Nevertheless, the classification of powers and duties put forward by Nikiforov may come in handy only because he singles out powers and duties dealing with occupational health and safety as a separate group trade unions' powers and duties.

\subsection{Powers and duties of trade unions in the} healthcare sector: inconsistencies in legislation

A comprehensive analysis the Law of Ukraine "On trade unions, their rights and guarantees of their activity", carried out against the background of theoretic principles of labor law, gives ample grounds for a conclusion that section II of the Law, entitled "The rights and duties of trade unions and their associations", was drawn up without proper legal expertise, complicating the perception of relevant rights, including the rights to protect labor interests of healthcare workers. It has been repeatedly emphasized in the theory of labor law that the legal term "powers" comprises both rights and duties. In this regard, the titles of articles 21 and 30 do not fit in the structure of this section of the Law. Hence, the title of article 21 "the powers of trade unions, their associations to protect the rights of citizens to labor and public control over the compliance with the labor legislation" and the title of article 30 "the powers of trade unions and their associations regarding healthcare, sport, tourism and environmental protection" have to be amended like this "the rights and duties of trade unions, their associations to protect the rights of citizens to labor and public control over the compliance with the labor legislation" and "the rights and dities of trade unions and their associations regarding healthcare, sport, tourism and environmental protection".

It is also necessary to point out that article 77 of the Law of Ukraine "On the principles of healthcare legislation in Ukraine", which is titled "Professional rights and privileges of healthcare and pharmaceutical industry workers", does not mention the rights of healthcare workers to form and join trade unions for the sake of ensuring the protection of their interests. Instead, article 30 of the Law of Ukraine "On trade unions, their rights and guarantees of their activity" specifies that trade unions and their associations arrange and carry out public control measures in order to verify if the rights of trade union members are respected in the healthcare sector. Furthermore, this article empowers trade unions and their associations to take part in the activities of expert, advisory and supervision panels at healthcare institutions, provide support and participate in various sporting and tourism events, held by sports and tourism organizations. Thus, the special provisions of article 77 of the Law of Ukraine "On the principles of healthcare legislation in Ukraine" do not go far enough to develop the general provisions of article 30 of the Law of Ukraine "On trade unions, their rights and guarantees of their activity" in respect of healthcare sector.

Besides, one of the main flaws of the existing legislation is the absence of detailed regulations concerning the exercise of trade unions' powers in the healthcare sector, which hampers proper application of this legislation creating additional obstacles for its enforcement. Considering the fact that the exercise of these powers often requires a detailed procedure for their enforcement, it is necessary to amend the Law of Ukraine "On trade unions, their rights and guarantees of their activity" and the Law of Ukraine "On the principles of healthcare legislation in Ukraine" by supplementing them with relevant articles and provisions. In particular, there has to be a detailed procedure for trade unions to enforce the existing legal requirements concerning the health insurance and social security of healthcare workers against occupational hazards, which is highly important when dealing biological hazards.

3.3. Protection function of trade unions in the healthcare sector with regards to occupational biological hazards

Judging by the mission and primary goals of trade unions, their rights and duties are designed mainly for performing the protection function. This function reveals itself in the enforcement of labor law. It is also worth pointing out that enforcement of labor law as part of trade unions' activities can manifest itself in two ways - as internal and external activities. In the course of internal application of labor law by trade unions they deal with the matters of internal management like setting up the executive board, establishing internal operational procedures as well as forming associations of trade unions in the healthcare sector. External application of labor law by trade unions takes place when they defend the rights and interests of healthcare workers. In this connection one cannot but mention that there two categories of healthcare workers who enjoy the support and protection of trade unions. One of these categories includes healthcare workers who are members of trade unions while the other category is represented by those who are not their members. Trade unions can protect the rights of healthcare workers who are not their members, if individual rights of such workers are violated, but they are not obliged by law to do so. Under the current law trade unions bear no responsibility for their refusal to represent such workers or protect their rights, even if trade unions are directly asked for help. But in case there is a violation of rights belonging to a group of people trade unions have to stand up for those rights regardless of whether such people are their members. In this respect I.V. Lagutina makes an interesting point claiming that "the protection function of trade unions reveals itself at all stages of legal regulation of labor: a) when new legislation is passed b) when the employer makes decisions concerning the application of certain provisions of labor legislation c) when trade unions provide support to workers by protecting their rights and legitimate interests (when settling individual and collective labor disputes)" [11, p.175].

In our opinion the fact that trade unions are not legally obliged to represent and protect

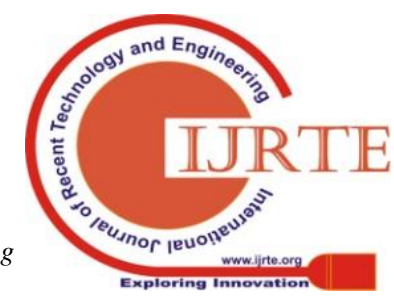


the rights of healthcare workers, who are not their members, is a major flaw of the current legislation. The situation can be improved by amending the Law of Ukraine "On trade unions, their rights and guarantees of their activity" and introducing an obligation of trade unions to represent workers who are not their members and protect such workers' interests at their request in case their rights are infringed or disputed. However, such workers, who are in fact quasi-members of trade unions, must not be allowed to enjoy the full scope of trade union members' rights. They must be able to exercise only those rights, which are necessary for the representation and protection of their interests by the trade unions. As for the rights to take part in the management of trade unions, they must be reserved for the members of trade unions only. This seems to be a good way to broaden the scope of representation and protection functions of trade unions, enabling them to provide protection to all healthcare workers, including those, who are not members of trade unions. This is particularly important when it comes to the representation and protection of healthcare workers by trade unions when there is a need to enforce the requirements of the law concerning the health insurance and social security of medical personnel faced with the consequences of occupational biological hazards.

It seems rather reasonable that the new term "quasi-member" of trade union should also include trainees. The thing is that according to the Regulation of the Cabinet of Ministers of Ukraine "On the procedure of concluding traineeship contracts for students of higher educational establishments and students of vocational training schools with enterprises, public institutions and organizations and the Model contract” №20 of 16 January, 2013 trainees are regarded as students of such educational establishments, who finished studying at the educational levels of "bachelor", "specialist", "junior specialist", "qualified worker" and continue their studies at the next level while simultaneously undergoing training at enterprises, public institutions and organizations within the relevant occupation or qualification on the conditions provided for in the contract during the time free from studies. Therefore, in general terms a trainee has a specific labor relationship with an employer. As a result, trainees also need the protection of trade unions in case their labor rights are infringed, for instance, when an employer does not provide safe working conditions or health insurance for a trainee and an occupational accident involving a biological hazard takes place. In particular, this conclusion is based on the provisions of paragraphs 13, 14 of the above-mentioned Governmental Regulation, requiring that a chief executive officer running an enterprise is responsible for ensuring proper working conditions, providing remuneration, maintaining appropriate standards of labor protection and occupational safety as well as sanitary conditions of work for trainees. Unfortunately, it is necessary to point out that this Governmental Regulation does not contain any specific provisions regarding traineeship in the healthcare sector, which makes it much more difficult for trade unions to protect the interests of healthcare workers in this sector, further complicating the protection of trainees in case of occupational accidents involving biological hazards.

\section{CONCLUSION}

As a summary it must be emphasized that current Ukrainian legislation has a number of flaws regarding the

protection of healthcare workers' rights by trade unions. One of the main flaws is the absence of any specific provisions regarding the rights of healthcare workers to form and join trade unions in the basic piece of medical legislation, which is the Law of Ukraine "On the principles of healthcare legislation in Ukraine". In addition, inconsistencies in article 77 of the Law of Ukraine "On the principles of healthcare legislation in Ukraine" and article 30 of the Law of Ukraine "On trade unions, their rights and guarantees of their activity" also damage the integrity of legislation applying to the protection of healthcare workers' rights. Furthermore, the absence of detailed procedures concerning the exercise of trade unions' powers in the healthcare sector is a major drawback, causing the need for relevant amendments to the current legislation. Such amendments can make a difference for healthcare workers if their rights to social security and health insurance against occupational biological hazards are violated.

It has also been discovered that it is possible for trade unions to protect the rights of healthcare workers even when they are not members of the trade union in case their individual rights are infringed, although trade unions are not legally obliged to do so. Since there is no liability of trade unions for refusing to protect such healthcare workers, it has been suggested that relevant amendments to the current legislation should be made, imposing an obligation upon trade unions to represent and protect the interests of workers regardless of their membership in trade unions, which will be helpful for healthcare workers who suffer from occupational accidents involving biological hazards. At the same time management powers in trade unions must be reserved solely for their members.

All of these legal flaws and gaps should be addressed during the ongoing medical reform, which has to imply protection of healthcare workers' interests as one of its priorities, especially when it comes to occupational hazards such as biological hazards.

Hopefully, the search for solutions to the problems of protecting the rights of healthcare personnel, including their rights to occupational safety against the background of biological hazards, highlighted in this article, will be fruitful in the course of medical reform in Ukraine and other countries. In particular, it will help overhaul the existing legislation by way of establishing effective legal guarantees for the protection of healthcare workers by trade unions.

\section{REFERENCES}

1. The Federation of Trade Unions of Ukraine. "the Healthcare Workers' Trade Union of Ukraine". Available at: http://www.fpsu.org.ua/pro-fpu/chlenski-organizatsiji/vseukrajinski-g aluzevi-profspilki/167-profspilka-pratsivnikiv-okhoroni-zdorov-ya-uk rajini

2. Sacadura-Leite E., Mendonça-Galaio L. Shapovalova O. · Pereira I. Rocha R. · Sousa-Uva A., (2018), Biological Hazards for Healthcare Workers: Occupational Exposure to Vancomycin-Resistant Staphylococcus aureus as an Example of a New Challenge, Karger. Vol. 36, №1 // Available at: https://www.karger.com/Article/FullText/487746\#ref3

3. Nagorna A.M., Sokolova M.P., Kononova I.G., (2016), The occurrence of occupational illnesses among healthcare workers as a medical and social problem, Ukrainian Journal of the Medical Issues of Labour. Vol. 47, №2, pg.6 // Available at 
http://irbis-nbuv.gov.ua/cgi-bin/irbis_nbuv/cgiirbis_64.exe?C21COM $=2 \& I 21 \mathrm{DBN}=$ UJRN\&P21DBN=UJRN\&IMAGE_FILE_DOWNLOA $\mathrm{D}=1 \&$ Image_file_name=PDF/Ujpmp_2016_2_2.pdf

4. The Law of Ukraine of 15 September 1999 "On trade unions, their rights and guarantees of their activity". Available at: http://zakon0.rada.gov.ua/laws/show/1045-14/print15185378020725 88

5. Befort S.F., (2000), Labor and Employment Law at the Millennium: A Historical Review and Critical Assessment. Boston College Law Review 43'2.

6. Deakin S., Morris G.S., (2005) Labour Law. Fourth Edition. Oxford, Portland, Oregon: Hart Publishing.

7. Lyutov N.L., (2009), Collective labor law of Great Britain. Moscow: Walters Cloover.

8. Chernyakova D.V., (2010), Labor relations in the countries of anglosaxon law. Moscow: Walters Cloover

9. Prokopenko V. I., (1998), Labor law of Ukraine. Kharkiv: Konsum.

10. Nikiforov V. Yu., (2004), Protection of social and labor rights of workers by trade unions in a market economy (theoretic and legal aspect). Kharkiv.

11. Lagutina I.V., (2007), Forms of protecting the labor rights of workers. Odessa.

12. The International Covenant on Civil and Political Rights. Available at https://treaties.un.org/doc/publication/unts/volume\%20999/volume-9 99-i-14668-english.pdf

13. The International Covenant on Economic, Social and Cultural Rights. Available https://treaties.un.org/doc/Treaties/1976/01/19760103\%2009-57\%20 PM/Ch_IV_03.pdf

14. Stone K.V.W., (2007), Revisiting the At-Will Employment Doctrine: Imposed Terms, Implied Terms, and the Normative World of the Workplace. Industrial Law Journal 36.

15. Chanisheva G. I., Bolotina N.B., (1999), Labor law of Ukraine. Kharkiv: Odessey

16. Available http://medprof.org.ua/reformuvannja-sistemi-okhoroni-zdorovja/

\section{AUTHORS PROFILE}

Yurii P. Burylo, Kyiv National Economic University of Vadim Hetman, Kyiv, Ukraine, , idorcid.org /0000-0001-8743-7739

Sergii Y. Vavzhenchuk, Taras Shevchenko National University of Kyiv,Kyiv, Ukraine, idorcid.org/0000-0002-6968-6720

Mariia V. Protsyshen, Kyiv National Economic University of Vadim Hetman,Kyiv, Ukraine, idorcid.org/0000-0001-8969-3808

Corresponding author: Email: aadvokat@gmail.com

Tel: +380674659480 